\author{
Aleksander Panasiuk* \\ Szczecin University

\section{THE STRUCTURE \\ OF THE HEALTH RESORT TOURISM BRAND}

\begin{abstract}
The use of a brand can be very profitable for both consumers and, above all, all producers. The benefits connected with brand building can be also obtained on the tourism market, including the market of health resort tourism. Therefore, the aim of the paper is to present the nature and use of the tourism brand concept on the market of health resort tourism. Activities building a health resort tourism brand require the involvement of all participants of the supply side of the tourism market (brand creators). These activities aim at the brand structure (elements of a health resort tourism product) through marketing (mainly promotion) and quality enhancing activities. Clients (patients, tourists) both consume and verify a tourism brand. A health resort tourism brand distinguished through the marketing concept and supported by identification activities (identity and image) makes it easier to achieve specific economic and social goals of an area of tourism reception. Moreover, it creates possibilities of fulfilling tourists' needs through high-quality services.
\end{abstract}

Keywords: tourism market, tourism brand, health resort tourism

\title{
Introduction
}

In modern times, a brand becomes one of the most effective management instruments, including the development of marketing activities for both commercial enterprises and non-profit institutions as well as for entities undertaking territorial

\footnotetext{
* E-mail addres: aleksander.panasiuk@wzieu.pl.
} 
marketing activities. The use of a brand can be very profitable for both consumers and, above all, all producers. The benefits connected with brand building can also be obtained on the tourism market, including the market of health resort tourism. Therefore, the aim of the paper is to present the nature and use of the tourism brand concept in the market of health resort tourism. The paper is mainly conceptual.

\section{Nature of a tourism brand}

Defining the nature of a brand requires describing relations between a product and a brand since both terms are closely related. A product is every material (goods) or non-material (services) effect of the production process sold to a consumer fulfilling particular needs and providing particular benefits. A product is a broader term and it is often connected with the production stage whereas a brand comes into existence at the moment of launching a product on the market and, then, it is associated with particular features and values.

A brand is not an unequivocal category and it is often defined as a name, term, sign, symbol, image or a combination of these elements created or drawn up in order to mark a physical product or a service and to distinguish it from the competitors' offer. ${ }^{1}$ By accepting the market strategy of brand building, an entity undertakes to continuously provide consumers with a set of features and benefits along with a purchased and, then, consumed product. ${ }^{2}$

The most important feature of a brand is its identification among other brands, or the so-called, "standard" products which are not brands. ${ }^{3}$ Brand awareness directly creates clients loyalty towards it and, at the same time, it gives the competitive advantage over other brands (products) on the market. The knowledge and value of a brand stem from its market power consisting of:

- loyalty towards a brand, as a purchasers' tendency to buy products of the same brand,

- brand awareness, as the effect resulting from its existence for a producer,

1 H. Mruk, I. Rutkowski, Strategia produktu, PWE, Warszawa 1994, p. 55; L. Garbarski, I. Rutkowski, W. Wrzosek, Marketing. Punkt zwrotny nowoczesnej firmy, PWE, Warszawa 2001, p. 10.

2 G. Urbanek, Zarzadzanie marka, PWE, Warszawa 2002, pp. 13-14.

3 S. Anholt, Culture Report. Progress Europe. The Perception of Europe, Stuttgart 2007, pp. 19-20; S. Anholt, The Anholt City Brands Index. How The World Views Its Cities, GMI 2006, p. 3. 
- quality level perceived by consumers and attributed to a brand, as the most important element making it beneficial to clients,

- associations connected with a brand (brand identity and image),

- other so-called assets of a brand, e.g. patents, registered trademarks and connections in the distribution system. ${ }^{4}$

Therefore, the existence and functioning of a brand mean that market participants obtain particular benefits. A strong brand provides purchasers with:

- relevant information about purchased products,

- confidence in making purchasing decisions,

- satisfaction from possessing and using a product of a given brand. ${ }^{5}$

Enterprises having brand products on the market gain the following benefits:

- higher effectiveness and efficiency of marketing activities,

- purchasers' loyalty towards a brand,

- more beneficial relation between price and profit, ${ }^{6}$

- development of a brand,

- rise in the number of middlemen,

- competitive advantage.

The functioning of brands can be very profitable for both consumers and, above all, all producers. The benefits identified with brand building can also be obtained on the tourism market.

In order to define a tourism brand, it is necessary to explain the nature of a tourism product. According to the marketing concept, a product can be everything which is the subject of the market exchange. A product is defined as an offer and it can be physical goods, a service or an idea. A tourism product has very often two kinds of meaning. From a narrow perspective, it is everything that a tourist buys (for example, transport, accommodation, catering and cultural services). ${ }^{7}$ This meaning is equal to the marketing concept of a productapplied as a term in marketing both material goods and services. Currently, a product

4 L. Light, Brand Erosion a Waste of Assets. Trust, Quality and Leadership Important in Creating Lasting Value, "Business Marketing" 1993, No. 8, p. 37; M.K. Witek-Hajduk, Zarządzanie marka, Difin, Warszawa 2001, pp. 52-67.

5 D.A. Aaker, Managing Brand Equity. Capitalizing on the Value of Brand Name, The Free Press, Toronto 1991, p. 17.

6 J. Marconi, Marketing marki, Liber, Warszawa 2002, pp. 53-58.

7 J. Kaczmarek, A.Stasiak, B.Włodarczyk, Produkt turystyczny. Pomyst. Organizacja. Zarządzanie, Polskie Wydawnictwo Ekonomiczne, Warszawa 2010, p. 75. 
is examined from the point of view of benefits (usefulness, pleasure) for clients rather than from that of sales value which, in a way, is of minor significance. ${ }^{8}$ A broad meaning is associated with the structure of tourism supply and concerns tourists' activities during a tourism trip and at a destination, including tourism advantages, devices and services which they use. ${ }^{9}$ From a slightly different perspective, a tourism product is defined as all goods and services produced and purchased in relation to a trip outside a place of living, before the beginning of a trip as well as during a stay outside a place of living. ${ }^{10}$

The term of a tourism brand should be associated with the term of a brand tourism product. The term of a tourism brand conveys the specificity of the issue more fully in conditions of the tourism market since it is not directly associated with the term of a brand product which is extensively used on the other markets. In a similar way to a tourism product, a tourism brand can also be defined from:

- a narrow, analogical perspective as in the case of brands used in other sectors of the economy (industry and service sectors),

- a broad perspective concerning tourism areas and attractions, ${ }^{11}$ as a set of activities aiming at a regional tourism product.

Therefore, a tourism brand from a narrow perspective should be associated with a service offer of particular tourism market entities. ${ }^{12}$ However, from a broad perspective it concerns: regions, areas, places and single tourist attractions. In the case of tourist attractions it is necessary to point out that they are surrounded by tourism infrastructure.

8 M. Zdon-Korzeniowska, Jak ksztaltować regionalne produkty turystyczne? Teoria i praktyka, Wydawnictwo Uniwersytetu Jagiellońskiego, Kraków 2009, p. 13.

9 A. Panasiuk, Rynek turystyczny. Studium strukturalne, Difin, Warszawa 2014, pp. 182-184; A. Panasiuk, Produkt turystyczny, Zeszyty Naukowe „Oeconomicus”, Wyższa Szkoła Zawodowa „Oeconomicus”, Szczecin 2001, pp. 73-75; H. Zawistowska, Rola Unii Europejskiej w poprawie jakości produktów turystycznych, in: Kierunki rozwoju badań naukowych $w$ turystyce, ed. G. Gołembski, Wydawnictwo Naukowe PWN, Akademia Ekonomiczna w Poznaniu, Warszawa 2003, p. 69.

10 S. Wodejko, Ekonomiczne zagadnienia turystyki, PWSH, Warszawa 1997, p. 23.

11 B. Meyer, Obszarowy produkt turystyczny jako efekt relacji pomiędzy grupami interesu, in: Gospodarka turystyczna a grupy interesu, ed. S. Wodejko, SGH, Warszawa 2006, p. 344.

12 A. Panasiuk (ed.), Marketing $w$ turystyce i rekreacji, Wydawnictwo Naukowe PWN, Warszawa 2013, pp. 259-261. 
Marketing activities connected with tourism brands in a narrow sense are aimed at consumers of tourism services provided by: hoteliers, travel agencies, tourism carriers, restaurateurs and the like. These consumers become tourists when they are at a destination and use other elements building the so-called broad tourism brand.

With reference to the marketing theory, a tourism brand in a broad sense takes a form similar to combined brands ${ }^{13}$ i.e. those created by a local government, tourism organizations and associations, and tourism services providers. Analogically, it can concern activities at the central level where tourism brands can be created by a national tourism organization and tourism services providers offering services on the domestic and international markets.

The above discussion thus allows us to formulate a - suggestively - broad definition of a tourism brand It should be understood as a comprehensive tourism product which is easily identified by potential tourists, stands out from competitors' offers and continuously represents a high level of quality. It is created in cooperation with government units, tourism organizations and tourism sector and significantly supported by marketing activities, and, at the same time, fulfilling tourism needs and creating tourists' satisfaction. Depending on the scope of influence, one can distinguish domestic tourism brands and those functioning on the international tourism market. At the same time, it means that the wider the extent of market influence is, the higher the position and greater market power a particular tourism brand potentially has.

The crucial issue which decides on the possibility of a tourism brand becoming recognizable is the constant improvement of quality. It entails the necessity of adjusting the tourism product concept to tourists' needs. The level of quality, from the point of view of human needs diversification, is treated, by both consumers and producers, as one of the most important effects of all kinds of activities, especially concerning services. The responsibility for creating the level of quality should be taken by particular entities which develop a tourism brand, that is tourism sector entities, a local government, tourism organizations responsible for building a new tourism product.

13 A. Panasiuk, Założenia koncepcji marki turystycznej, „Marketing i Rynek” 2004, No. 8, pp. 2-7; A. Panasiuk, Marka turystyczna jako instrument zarządzania regionalna gospodarka turystyczną w warunkach sytuacji kryzysowych, „Współczesne Zarządzanie” 2013, No. 1, pp. 21-30. 


\section{Health resort tourism}

Health resort tourism is a form of medical tourism and constitutes an element of the tourism market distinguished from the point of view of motivation for tourist activities. This form of tourism matches an offer which results from comprehensive functioning of the tourism market entities with a specialist offer meeting the needs of tourists who choose health resort tourism (i.e. patients). The part of the specialist health resort tourism offer can be a basis for creating demand of tourists staying in health resorts for some other than therapeutic reasons. Then, the health resort tourism offer is a supplementary way to fulfil their touristic needs in the health resort destination.

Health resort tourism is defined as visits involving sanatorium treatment, rehabilitation treatment and health resort treatment, and are connected with natural medicine therapy provided after a consultation with a doctor from a health resort. ${ }^{14}$ Therefore, a basis for health resort tourism is health resort treatment socially considered not only as part of medicine, but also an element of the tourism sector. Health resort treatment takes the form of treatment in natural medicine centres where patients choose from the therapies using natural wealth (health resort advantages), including curative waters, peloid, or gases. An important part of health resort treatment is staying in a place with a local curative climate. Apart from treating patients, prevention is also an important health resort activity. ${ }^{15}$

Health resort tourism should be treated as an important and specific form ofmedical tourism. The special nature of health resort tourism results from, above all, the purpose and motive for a trip to a place considered a health resort and also from the needs to make use of services provided by health resort companies. The main motives for health and wellness activities include, among others: strength regeneration, influence on health and wellbeing, active holiday. ${ }^{16}$ These aims can be achieved not only through health resort tourism, but also,

${ }_{14}$ M. Januszewska, Znaczenie produktu uzdrowiskowego $w$ rozwoju turystyki $w$ Polsce, in: Markowe produkty turystyczne, ed. A. Panasiuk, Fundacja na rzecz Uniwersytetu Szczecińskiego, Szczecin-Niechorze 2004, p. 219.

15 E.Bańkowska, Szanse i zagrożenia Sopotu jako miejscowości uzdrowiskowej, in: Turystyka uzdrowiskowa. Stan i perspektywy, Publikacje Wyższej Szkoły Turystyki i Hotelarstwa w Sopocie, Gdańsk, 1999, p. 191.

16 W.W. Gaworecki, Turystyka, Polskie Wydawnictwo Ekonomiczne, Warszawa 2000, p. 36. 
for example, through active or holiday tourism..$^{17}$ One should bear in mind that, with regard to the demand, a health resort tourist also creates other needs fulfilled by the remaining elements of the tourism supply structure.

C. Kaspar and P. Fehrlin suggest defining health resort tourism as a set of relations, activities and phenomena which result from stays that people choose because of health and wellness reasons, and from visits to health resorts and returns to their places of living. ${ }^{18}$

\section{Health resort tourism market}

The tourism market can be analyzed considering industry aspects (hotels, travel agencies, carriers, etc.), segment criteria, or purposes (motives) of travelling. In practice, every tourism enterprise can divide the market according to their own selected criteria. For cognitive and practical reasons, each market and its features can be described through a subject of exchange, entities existing on this particular market, demand and supply features as well as the so-called conditions for entering the market. The knowledge of these tourism market features is necessary to make rational decisions by tourism sector entities. ${ }^{19}$

The health resort tourism market is one kind of tourism market. This market is isolated when it comes to motives for travelling, i.e. trips whose main or additional purpose is to influence health as well as physical and mental condition of a tourist. The health resort tourism market is also a special business combining elements of other tourism businesses, mainly the hotel industry, but, at the same time, involves the medical business, i.e. health resort treatment.

The aforementioned definition by C. Kaspar and P. Fehrlin is a basis for defining the essence of the health resort tourism market and, then, indicating its elements of the subject and object structure. The health resort tourism market, from the point of view of subjects, is a process in which clients (health resort tourists) and service providers (producers of tourism and health services, and health resort

17 A. Panasiuk (ed.), Gospodarka turystyczna, Wydawnictwo Naukowe PWN, Warszawa 2008, pp. 231-235.

18 C. Kaspar, F. Ferlich, Marketing Konzeption der Heilböund Kurorte B16, Hochschule St. Gallen 1979, p. 14.

19 J. Altkorn, Marketing w turystyce, Wydawnictwo Naukowe PWN, Warszawa 1998, p. 19. 
tourism destinations - i.e. health resorts) define a subject of the market exchange - services in a health resort, their prices, terms and conditions of sale. ${ }^{20}$ Following this interpretation, the health resort tourism is an element of the tourism market and has two fundamental functions of:

- cure, rehabilitation and prevention,

- leisure.

Through functions mentioned above, health resort tourism market offers (tourist and medical) mix with offers aiming at demand which is met by the remaining tourism markets, e.g. leisure, cognitive and adventure tourism. Therefore, health resort tourism is created through combining medical and preventive functions with the tourist function. ${ }^{21}$ Taking the spatial aspect of health resort tourism into consideration, this takes place in a health resort that has gained the status of a health resort, or else, an area where health and wellness services are provided, and which has been selected in order to use and protect its natural medicine resources. ${ }^{22}$

The fundamental entities functioning in the health resort tourism market are:

a) regarding the demand:

- health resort tourists (patients),

- other tourists (not patients) staying in a health resort and using offered services as supplementary ones;

b) regarding the supply:

- health resort enterprises (e.g. sanatoriums, natural medicine centres, spa and wellness centres),

- other tourism enterprises offering services for both patients and other tourists,

- enterprises offering tourists, including patients, paratourist services whose main function is fulfilling needs of regular residents of a health resort;

${ }^{20}$ A. Panasiuk (ed.), Ekonomika turystyki i rekreacji, Wydawnictwo Naukowe PWN, Warszawa 2011, pp. 113-114.

21 D. Dryglas, Ksztattowanie produktu turystycznego uzdrowisk w Polsce, Uniwersytet Jagielloński, Kraków 2006, p. 264.

22 A. Lewandowska, Turystyka uzdrowiskowa. Materiaty do studiowania, Wydawnictwo Naukowe Uniwersytetu Szczecińskiego, Szczecin 2007, p. 21. 
c) regarding the tourism policy:

- authorities regulating functioning of the health resort treatment and tourism sector,

- local governments of health resorts and their associations (Association of Polish Spa Communities),

- health resort tourism organizations (Chamber of Commerce "Polish Spas"),

- tourism business organizations.

The health resort tourism market can be developed mainly owing to supply elements of the general tourism market. It is supplemented by elements relevant to motives for health resort tourism, i.e. those resulting from activities of sanatoriums and health resort hospitals which are a special kind of health and wellness accommodation. The motives typically identified with health resort tourism are treatment and rehabilitation. The typical supply elements within the health resort tourism market are health service (as an element of the medical services market) and health and wellness centres (as a form of activity including both medical and tourism service markets). Although such aspects as the use of health resorts advantages (e.g. brines, peloid), activities of spa and wellness centres, and local health resort infrastructure (e.g. mineral water pump rooms, spa parks) largely affect patients' demand, they also have influence on the demandof tourists coming to health resorts for other purposes. Thus, the said elements of the supply structure provide them with complementary services.

\section{Components of the health resort tourism brand}

Entities involved in creating tourism are of great importance in the concept of creating a brand tourism product. Entities affecting a brand health resort tourism product include entities representing the supply side of the market, especially health resort enterprises with support from local governments, institutions involved in tourism activities and residents of health resorts and regions.

The structure elements of a brand can be a basis for creating a health resort tourism product and to promote and give it a title of a brand product require an individual approach. The model of the structure of a health resort tourism brand is shown in Figure 1. 


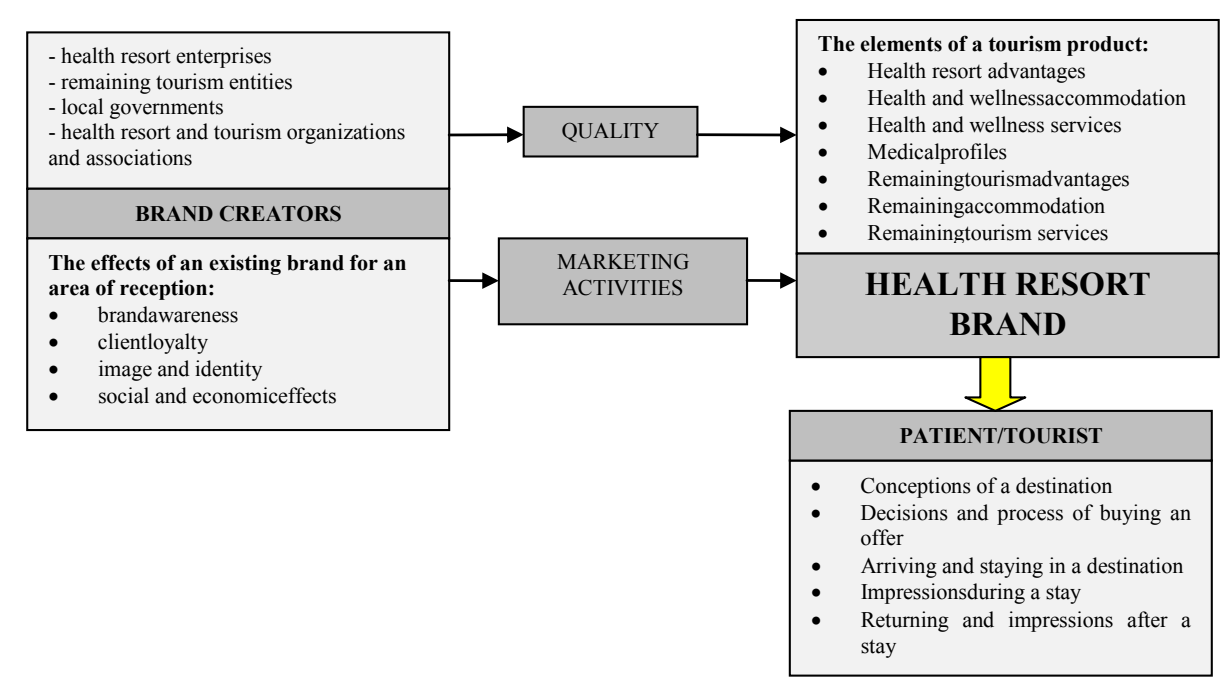

Fig. 1. Structure of the health resort tourism brand

Source: A. Panasiuk, Marka turystyczna. Założenia metodyczne, in: Markowe produkty turystyczne, ed. A. Panasiuk,University of Szczecin Foundation, Niechorze 2004, p. 123.

Discussing a health resort tourism brand, two elements must be emphasized, i.e. brand creators and consumers - patients (tourists). Brand creators are entities of the supply structure responsible for functioning of health resort tourism in a place and region and have to achieve as good results as possible. Owing to marketing tools and high-quality services, a health resort tourism product- brand product- is created on the basis of the existing tourism potential. One should also remember that a brand product is created in direct cooperation with patients (tourists) for whom this product should be attractive.

\section{Conclusion}

The scope of issues addressed constitutes the synthesis of matters connected with tourism market structures together with places of health resort tourism. The development of the tourism market concerns both the supply and the demand side. Supply is developed through new innovative offers launched on the market. What also matters within the tourism market is creating new tourism destinations 
providing broad and/or specific tourism offers. Changes in demand can be observed owing to new forms of tourism. These processes are mutually influential. The general tourism market develops owing to specific markets. Specific markets expand their structure through the general and comprehensive market which can be local, regional and national. It appears that the structural development of the tourism market is determined by the development of specific markets (including health resort tourism) whereas the development of specific markets is not possible without the well-developing tourism market.

Activities building a health resort tourism brand require involvement of all participants of the supply side of tourism market (brand creators). These activities aim at the brand structure (elements of a health resort tourism product) through marketing (mainly promotion) and quality enhancing activities. Clients (patients, tourists) both consume and verify a tourism brand. A health resort tourism brand distinguished through the marketing concept and supported by identification activities (identity and image) makes it easier to achieve specific economic and social goals of an area of tourism reception. Moreover, it creates possibilities of fulfilling tourists' needs through high-quality services.

\section{References}

Aaker D.A., Managing Brand Equity. Capitalizing on the Value of Brand Name, The Free Press, Toronto 1991.

Anholt S., Culture Report. Progress Europe. The Perception of Europe, Stuttgart 2007. Anholt S., The Anholt City Brands Index. How The World Views Its Cities, GMI2006. Altkorn J., Marketing w turystyce, Wydawnictwo Naukowe PWN, Warszawa 1998.

Bańkowska E., Szanse i zagrożenia Sopotu jako miejscowości uzdrowiskowej, in:

Turystyka uzdrowiskowa. Stan i perspektywy, Publikacje Wyższej Szkoły

Turystyki i Hotelarstwa w Sopocie, Gdańsk 1999.

Dryglas D., Ksztaltowanie produktu turystycznego uzdrowisk w Polsce, Uniwersytet Jagielloński, Kraków 2006.

Gaworecki W.W., Turystyka, Polskie Wydawnictwo Ekonomiczne, Warszawa 2000.

Januszewska M., Znaczenie produktu uzdrowiskowego w rozwoju turystyki w Polsce, in:

Markowe produkty turystyczne, ed. A. Panasiuk, Fundacja na rzecz Uniwersytetu Szczecińskiego, Szczecin-Niechorze 2004.

Kaczmarek J., Stasiak A., Włodarczyk B., Produkt turystyczny. Pomysł. Organizacja.

Zarzadzanie, Polskie Wydawnictwo Ekonomiczne, Warszawa2010.

Kaspar C., Ferlich F., Marketing Konzeption der HeilböundKurorte B16, Hochschule St. Gallen 1979.

Kotler Ph., Marketing. Analiza, planowanie, wdrażanie i kontrola, Gebethner i S-ka, Warszawa 1994. 
Lewandowska A., Turystyka uzdrowiskowa. Materiały do studiowania, Wydawnictwo Naukowe Uniwersytetu Szczecińskiego, Szczecin 2007.

Light L., Brand Erosion a Waste of Assets. Trust, Quality and Leadership Important in Creating Lasting Value, "Business Marketing" 1993, No. 8.

Marconi J., Marketing marki, Liber, Warszawa 2002.

Meyer B., Obszarowy produkt turystyczny jako efekt relacji pomiędzy grupami interesu, in: Gospodarka turystyczna a grupy interesu, ed. S. Wodejko, SGH, Warszawa 2006.

Mruk H., Rutkowski I., Strategia produktu, PWE, Warszawa 1994.

Panasiuk A. (ed.), Ekonomika turystyki i rekreacji, Wydawnictwo Naukowe PWN, Warszawa 2011.

Panasiuk A. (ed.), Gospodarka turystyczna, Wydawnictwo Naukowe PWN, Warszawa 2008.

Panasiuk A., Marka turystyczna jako instrument zarzadzania regionalna gospodarka turystyczna w warunkach sytuacji kryzysowych, "Współczesne Zarządzanie" 2013, No. 1.

Panasiuk A., Marka turystyczna. Założenia metodyczne, in: Markowe produkty turystyczne, A. Panasiuk (ed.), Fundacja na rzecz Uniwersytetu Szczecińskiego, Szczecin-Niechorze 2004.

Panasiuk A. (ed.), Marketing $w$ turystyce i rekreacji, Wydawnictwo Naukowe PWN, Warszawa 2013.

Panasiuk A., Produkt turystyczny, Zeszyty Naukowe „Oeconomicus”, Wyższa Szkoła Zawodowa „Oeconomicus”, Szczecin 2001.

Panasiuk A., Rynek turystyczny. Studium strukturalne, Difin, Warszawa 2014.

Panasiuk A., Założenia koncepcji marki turystycznej, "Marketing i Rynek" 2004, No. 8.

Urbanek G., Zarzadzanie marka, PWE, Warszawa 2002.

Witek-Hajduk M.K., Zarządzanie marka, Difin, Warszawa 2001.

Wodejko S., Ekonomiczne zagadnienia turystyki, PWSH, Warszawa 1997.

Zawistowska H., Rola Unii Europejskiej w poprawie jakości produktów turystycznych, in: Kierunki rozwoju badań naukowych w turystyce, ed. G. Gołembski, Wydawnictwo Naukowe PWN - Akademia Ekonomiczna w Poznaniu, Warszawa 2003.

Zdon-Korzeniowska M., Jak kształtować regionalne produkty turystyczne? Teoria i praktyka, Wydawnictwo Uniwersytetu Jagiellońskiego, Kraków 2009.

\section{STRUKTURA MARKI TURYSTYKI UZDROWISKOWEJ}

\section{Streszczenie}

Ze stosowania marki wynikają wysokie korzyści zarówno dla konsumentów, jak i przede wszystkim producentów. Korzyści związane z kreowaniem marek można uzyskiwać także w warunkach rynku turystycznego, w tym turystyki uzdrowiskowej. Stąd celem niniejszego opracowania jest prezentacja istoty i wykorzystania koncepcji marki turystycznej na rynku turystyki uzdrowiskowej. Działania objęte kształtowaniem 
marki turystyki uzdrowiskowej wymagają zaangażowania wszystkich uczestników strony podażowej rynku turystycznego (kreatorzy marki). Działania te skierowane są poprzez działania projakościowe i marketingowe (głównie promocyjne) na strukturę marki (elementy produktu turystyki uzdrowiskowej). Konsumentem a jednocześnie weryfikatorem rynkowym marki turystycznej są konsumenci (kuracjusze, turyści). Marka turystyki uzdrowiskowej wyodrębniona poprzez koncepcję marketingową, wsparta działaniami identyfikującymi (tożsamość i wizerunek) sprzyja realizacji osiągania określonych celów ekonomicznych i społecznych obszarów recepcji turystycznej. Ponadto stwarza możliwości zaspokojenia potrzeb turystów na wysokim poziomie jakościowym.

Słowa kluczowe: rynek turystyczny, marka turystyczna, turystyka uzdrowiskowa 